\title{
Manajemen Pembiayaan Pendidikan Lembaga Filantropi Yatim Mandiri dalam Pemberdayaan Mahasiswa Yatim (Study Analisis Program MEC)
}

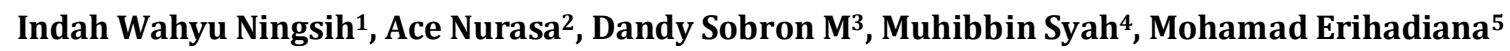

1,2,3,4,5Universitas Islam Negeri Sunan Gunung Djati Bandung, Indonesia

E-mail: indah.aysar@gmail.com, acenurasa@gmail.com, dandysobronm@gmail.com, muhibbinsyah@yahoo.com, erihadiana@uinsgd.ac.id

\begin{tabular}{l}
\hline Article Info \\
\hline Article History \\
Received: $2021-11-10$ \\
Revised: $2021-11-28$ \\
Published: $2021-12-08$
\end{tabular}

Keywords:

Management;

Financing;

Student;

Orphan.

\begin{abstract}
The purpose of this study was to understand how the strategy in financing education managed by the Yatim Mandiri Surabaya foundation in empowering orphans and poor people. The approach used in this research is a qualitative approach. A qualitative approach is a research procedure that produces descriptive data in the form of written or spoken words from people and observable behavior. The results of this study indicate that MEC is one of the flagship programs launched by Yatim Mandiri, MEC itself is an education and training program intended for retired orphans who are in the age range of 17-21 years. The purpose of this program is to produce orphaned entrepreneurs with the provision of three pillars, namely academic, religious and entrepreneurial. The education funding for the MEC program was obtained from Yatim Mandiri, which allocated 7\% of the total funds collected by Yatim Mandiri. Each MEC student will receive a grant of 32 million during the one year education period in the MEC dormitory. This fund is used to finance education and dormitories for one year, starting from the time students register and complete the education and cadre stages for one year.
\end{abstract}

\begin{tabular}{l}
\hline Artikel Info \\
\hline Sejarah Artikel \\
Diterima: $2021-11-10$ \\
Direvisi: $2021-11-28$ \\
Dipublikasi: $2021-12-08$
\end{tabular}

Kata kunci: Manajemen; Pembiayaan; Mahasiswa; Yatim. \begin{abstract}
Abstrak
Tujuan penelitian ini adalah untuk memahami bagaimana strategi dalam pembiayaan pendidikan yang dikelola oleh yayasan Yatim Mandiri Surabaya dalam memberdayakan anak-anak yatim dan dhuafa. Adapun pendekatan yang digunakan dalam penelitian ini adalah pendekatan kualitatif. Pendekatan kualitatif adalah prosedur penelitian yang menghasilkan data deskriptif berupa kata-kata tertulis atau lisan dari orang-orang dan perilaku yang dapat diamati. Hasil penelitian ini menunjukkan bahwa MEC merupakan salah satu program unggulan yang digulirkan Yatim Mandiri, MEC sendiri merupakan program pendidikan dan pelatihan yang diperuntukan bagi purna Yatim yang berada dalam rentang usia 17 - 21 tahun. Tujuan dari progam ini ialah mencetak enterpreuner yatim dengan pembekalan tiga pilar yaitu akademik, keagamaan dan wirausaha. Dana pembiyaan pendidikan program MEC diperoleh dari Yatim Mandiri yang mengalokasikan sebesar 7\% dari keseluruhan dana yang dihimpun Yatim Mandiri. Setiap mahasiswa MEC akan memperoleh dana sebesar 32 juta selama masa pendidikan satu tahun di asrama MEC. Dana ini dipergunakan sebagai pembiayaan pendidikan dan asrama selama satu tahun, terhitung sejak mahasiswa mendaftar dan menyelesaikan tahapan pendidikan dan pengkaderan selama satu tahun.
\end{abstract}

\section{PENDAHULUAN}

Pembiayaan merupakan komponen penting dalam penyelenggaraan pendidikan karena menjadi faktor kunci bejalannya semua program yang telah telah direncanakan. Salah satu kunci keberhasilan dalam pembangunan pendidikan, terletak pada kemampuan SDM dalam mengelola potensi sumber dana serta mengelola dana dengan mengacu pada kebutuhan inti dan skala prioritas secara efektif dan efisien, pembiayaan pendidikan menurut (Arifudin, 2021) bahwa merupakan tanggung jawab bersama antara Pemerintah, pemerintah daerah, dan masyarakat. Hal ini sesuai amanat UU Sistem Pendidikan
Nasional Nomor 20 tahun 2003 Pasal 46 ayat (1). Pembiayaan pendidikan merupakan hubungan saling keterkaitan yang di dalamnya terdapat komponen-komponen yang bersifat mikro dan makro pada satuan pendidikan. Setiap komponen memiliki fungsi yang berbeda-beda, namun memiliki tujuan akhir yang sama, yaitu: a) peningkatan potensi SDM yang berkualitas; b) penyediaan komponen-komponen sumbersumber pembiayaan pendidikan; c) penetapan sistem dan mekanisme pengalokasian dana; d) pengefektifan dan pengefisiensian penggunaan dana; e) akuntabilitas (dapat dipertanggung jawabkan) dari aspek keberhasilan dan mudah 
terukur pada setiap satuan pendidikan; f) meminimalisi terjadinya permasalahanpermasalahan yang terkait denga penggunaan pembiayaan pendidikan.

Terkait dengan model pembiayaan pendidikan, (Wibisono, 2007) berpendapat bahwa terdapat 4 (empat) model pembiayaan pendidikan, yaitu: 1) subsidi penuh dari jenjang pendidikan dasar sampai pendidikan tinggi; 2) pendidikan gratis pendidikan tinggi diberikan kepada peserta didik sampai usia tertentu; 3) pendidikan gratis diberikan sampai SMA, dan pendidikan tinggi tetap membayar SPP sekalipun masih menerima subsidi; dan 4) semua jenjang pendidikan wajib membiayai diri sendiri. Penggalian sumber dana dapat diperoleh dari upaya kerja sama dengan industri atau memanfaatkan bantuan CSR (corporate social responsiblity), membentuk komunitas alumni, bersumber dari filantropi atau bersumber dari orangtua/wali peserta didik. Tantangan lain dalam pembiayaan adalah kenaikan biaya pendidikan biaya pendidikan seperti yang dijelaskan oleh (Ferdi, 2013) bahwa oleh kenaikan pembiayaan pendidikan disebabkan antara lain a) kenaikan harga (rising prices); b) perubahan relative gaji guru (teacher's salary); c) perubahan dalam populasi anak sekolah; d) meningkatnya standar pendidikan (educational standard); dan f) meningkatnya tuntutan terhadap pendidikan yang lebih tinggi (higher education), porsi anggaran pendidikan yang ditetapkan pemerintah setiap tahun mengalami kenaikan untuk mengakomodir amanat $20 \%$ dari dari APBN, hal ini dapat dilihat pada gambar ilustrasi berikut ini:

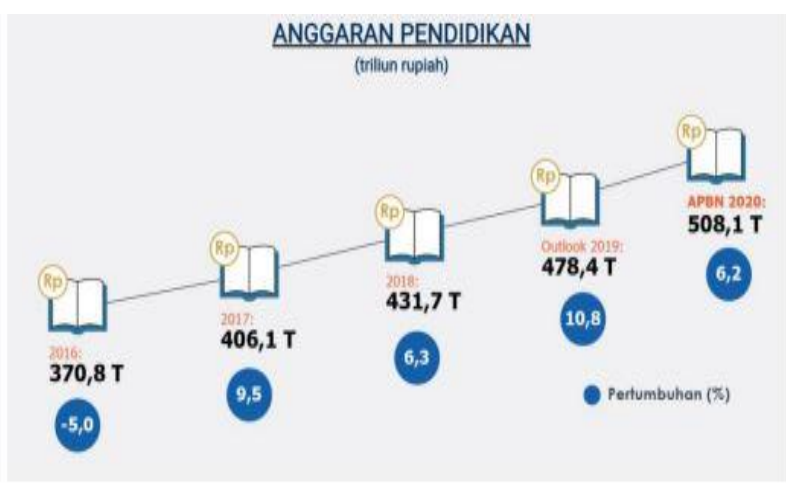

Gambar 1. Anggaran Kementrian Pendidikan dan Kebudayaan dari tahun 2016-2020

Sumber : https://www.kemenkeu.go.id/

Dalam Anggaran Pendapatan dan Belanja Negara (APBN) 2020 Pemerintah telah menganggarakan 508,1 triliun untuk Kementerian Pendidikan, Kebudayaan serta Riset dan Teknologi Republik Indonesia. Kebijakan pemakaian anggaran di bidang pendidikan terbesar diarahkan pada program Wajib Belajar 12 tahun melalui program BOS dan program Indonesia Pintar untuk 54,8 juta siswa. Sedangkan untuk program KIP kuliah dianggarakan sebesar 6,7 triliun untuk 819,4 ribu mahasiswa diperlihatkan pada gambar ilustrasi 2. Anggaran KIP kuliah ini terbilang kecil untuk ditujukan kepada 8,6 juta mahasiswa.

Disisi lain bahwa penduduk muslim Indonesia memiliki persentase $88,1 \%$ dari total penduduk berdasarkan data The Pew Forum of Religion and Public Life pada 2010. Umat Islam dengan berbagai kewajibannya seperti zakat, infaq, shadaqah, dan wakaf, dapat hadir menjadi salah satu solusi dalam pendanaan pendidikan di Indonesia. Zakat sebagai salah satu dana kebaikan dalam Islam (filantropi Islam) sampai saat ini belum dikelola secara maksimal dan produktif. Hal ini dapat dilihat berdasarkan studi Pusat Kajian Strategis (Puskas) Badan Amil Zakat Nasional BAZNAS potensi zakat di Indonesia mencapai 233,8 Triliun, sedangkan diketahui bahwa penghimpunan ZIS secara nasional pada 2019 melalui OPZ resmi mencapai 10 Triliun atau masih 5,2 persen dari potensi zakat (Baznas, 2020). Menurut (Fasa, 2020) bahwa Zakat, infak, sedekah dan wakaf merupakan pranata keagamaan yang berfungsi untuk mewujudkan keadilan sosial bagi seluruh umat manusia, dengan memperhatikan dan meningkatkan kepedulian terhadap masyarakat yang kurang mampu.

Pemberdayaan untuk meningkatkan sumber daya manusia terkhusus untuk anak-anak bangsa yang tidak mampu melanjutkan pendidikan karena berbagai macam kendala. Oleh karena itu, sistem pengelolaan dana umat yang selama ini berjalan perlu disempurnakan agar pelaksanaan zakat, infak, sedekah dan wakaf bukan hanya sebatas pelaksanaan kewajiban keagamaan tetapi dapat melakukan pemberdayaan institusi keuangan publik, sehingga lebih berdaya guna dan dapat dipertanggungjawabkan secara amanah, adil dan transparan. Perintah berzakat mengandung dua dimensi, yaitu vertikal kepada sang khalik sebagai bukti kepatuhan menjalankan perintah-Nya, disamping bersifat horizontal sesama manusia.

Manusia sebagai ciptaan Allah SWT, Menyadari bahwa semua yang dilakukan adalah tuntunan dari Allah SWT, oleh sebab itu apa yang diperintahkan oleh Allah wajib hukumnya wajib untuk di ta'ati. Demikian halnya perintah untuk 
menunaikan zakat bagi setiap orang Islam di muka bumi ini dijelaskan dalam Al-Qur" an surah At-Taubah ayat 11 yang artinya : "Jika mereka bertaubat, mendirikan sholat dan menunaikan zakat, maka (mereka itu) adalah saudarasaudaramu seagama. Dan Kami menjelaskan ayat-ayat itu bagi kaum yang mengetahui."

Hingga saat ini, sudah ada 17 lembaga amil zakat yang telah mendapatkan izin dari Kementrian Agama untuk skala nasional. LAZ skala nasioanal diantaranya: LAZ Rumah Zakat Indonesia, LAZ Daarut Tauhid, LAZ Baitul Maal Hidayatullah, LAZ Dompet Dhuafa Republika, LAZ Nurul Hayat, LAZ Inisiatif Zakat Indonesia, LAZ Yatim Mandiri Surabaya, LAZ Lembaga Manajemen Infak Ukhuwah Islamiyah, LAZ Dana Sosial Al Falah Surabaya, LAZ Pesantren Islam Al Azhar, LAZ Baitulmaal Muamalat, LAZ Lembaga Amil Zakat Infak dan Shadaqah Nahdatul Ulama (LAZIS NU), LAZ Global Zakat, LAZ Muhammadiyah, LAZ Dewan Da'wah Islamiyah Indonesia, LAZ Perkumpulan Persatuan Islam, LAZ Rumah Yatim Arrohman Indonesia. Lembaga amil zakat nasional, berfungsi sebagai lembaga intermediasi antara muzakki dan mustahik, yaitu menjembatani kepentingan mustahiq dalam memberikan zakat, infak, dan shadaqahnya kepada mustahiq (Labetubun, 2021). Yatim Mandiri, merupakan salah satu organisasi pengelola amil zakat di Indonesia yang berfokus untuk memandirikan anak-anak yatim melalui pendidikan.

Kelahirannya berawal dari kegelisahan beberapa orang aktivis panti asuhan di Surabaya yaitu Sahid Has, Sumarno, Hasan Sadzili, Syarif Mukhodam dan Moch Hasyim yang melihat anakanak yatim yang lulus SMA di panti asuhan. Karena tidak semua panti asuhan mampu untuk menyekolahkan para anak binaan sampai ke perguruan tinggi atau mencarikan mereka lapangan pekerjaan, sehingga sebagian besar anak-anak yatim ini dipulangkan kembali kepada keluarganya yang masih ada. Setelah mereka pulang kembali, maka hidup mereka tidak mengalami perubahan kembali seperti semula. Melihat kondisi seperti ini, mereka berpikir bagaimana anak-anak ini bisa hidup mandiri tanpa bergantung lagi kepada orang lain. Kemudian mereka merancang sebuah yayasan yang bergerak dalam bidang pendidikan anak yatim purna asuh dari panti asuhan dengan program mengikutsertakan anak-anak yatim kursus keterampilan.

Untuk mewujudkan mimpi memandirikan anak-anak yatim itu, maka pada tanggal 31 Maret
1994 dibentuklah sebuah yayasan yang diberi nama Yayasan Pembinaan dan Pengembangan Panti Asuhan Islam dan Anak Purna Asuh (YP3IS). Pada tanggal 22 Juli 2008 Yatim Mandiri terdaftar di Depkumham dengan nomor: AHU2413.AH.01.02.2008. Dengan nama baru Yatim Mandiri diharapkan akan menjadi lembaga pemberdaya anak yatim yang kuat di negeri ini. Yatim Mandiri juga telah resmi terdaftar sebagai Lembaga Amil Zakat Nasional berdasarkan SK. Kemenag RI no 185 tahun 2016.Sampai saat ini Yatim Mandiri sudah memiliki 46 kantor layanan di 14 Propinsi di Indonesia.

Dengan berbagai program kemandirian yang ada, harapannya Yatim Mandiri semakin berkembang lebih baik dan mampu menebar manfaat lebih luas. Lembaga Yatim Mandiri mendayagunakan dana ziswafnya untuk pembangunan dan pengembangan lembaga pendidikannya. Keunikan dari Yatim Mandiri adalah, sebagai lembaga pengelola zakat ternyata donasi yang mereka kumpulkan dari para donatur didominasi dari dana infaq dan shadaqah dibandingkan dana zakat. Penerimaan dana zakat pada bulan Mei 2019 sebanyak Rp. 1.811.139.525 dan dana infak/sedekah sebanyak Rp. 13.673.876.035. Fokus penyaluran dana program pendidikan pada laporan keuangan terakhir yaitu Rp 6.803.799.034 (Keuangan Yatim Mandiri, 2019). Penyaluran dana zakat yang dipeoleh Yatim Mandiri ke anak-anak Yatim dan Dhuafa sudah sepenuhnya merata untuk Indonesia. Jumlah penerima manfaat dari lembaga Yatim Mandiri sebanyak 162.087.

Tujuan penelitian ini sebagai acuan dalam mengembangkan sumbersumber pembiayaan pendidikan melalui dana ziswaf secara optimal. Strategi implementasi yang dilakukan Yatim Mandiri terdiri dari 3 hal yaitu pengumpulan dana (fund raising), iklan (advertising), kolaborasi dengan perusahaan (collaborating). Implikasi dari strategi pembiayaan filantropi Yatim Mandiri dalam memberdayakan anak-anak yatim adalah mampu memberikan pendidikan gratis untuk anak yatim dan dhuafa serta bantuan lainnya yang dapat meningkatkan hasil pendidikan (Murtika, 2017)

Model lain pembiayaan pendidikan berbasis filantropi telah dilakukan oleh Dompet Dhuafa yang menyelenggarakan program Sekolah Guru Indonesia yaitu pengiriman guru ke daerah 3T (Tertinggal, Terluar, Terdepan) menggunakan zakat produktif karena guru yang dikirim ke daerah penempatan merupakan bagian dari asnaf fi sabiililah. Program SGI ini sangat 
dirasakan manfaatnya baik untuk guru yang mengikuti program tersebut juga masyarakat di lokasi penempatan(Shofa, 2017).

Berdasarkan pemaparan di atas kami tertarik untuk meneliti mengenai Manajemen Pembiayaan Pendidikan Lembaga Filantropi Yatim Mandiri dalam Pemberdayaan Mahasiswa Yatim (Study Analisis Program MEC).

\section{METODE PENELITIAN}

Penelitian ini berusaha untuk menganalisis dan mendeskripsikan manajemen pembiayaan pendidikan berbasis filantropi, strategi implementasi pengumpulan dan penyaluran dana zakat, implikasi strategi pembiayaan pendidikan di Lembaga Yatim Mandiri Surabaya dalam memberdayakan anak-anak yatim. Jenis penelitian yang digunakan pada penelitian ini adalah berupa studi kasus. Menurut (Rahayu, 2020) bahwa studi kasus adalah penelaahan empiris yang menyelidiki suatu gejala dalam latar kehidupan nyata. Hasil penelitian ini dikumpulkan dengan data primer dan data skunder, penentuan teknik pengumpulan data yang tepat sangat menentukan kebenaran ilmiah suatu penelitian. Teknik pengumpulan data yang digunakan dalam penelitian ini adalah:

\section{Observasi}

Observasi merupakan suatu pengamatan secara langsung dengan sistematis terhadap gejala-gejala yang hendak diteliti (Arikunto, 2006). Dengan metode ini, peneliti dapat melihat dan merasakan secara langsung suasana dan kondisi subyek penelitian. Halhal yang diamati dalam penelitian ini adalah tentang manajemen pembiayaan pendidikan lembaga filantropi yatim mandiri dalam pemberdayaan mahasiswa yatim.

2. Wawancara

Teknik wawancara dalam penelitian ini adalah wawancara terstruktur, yaitu wawancara yang dilakukan dengan menggunakan pedoman yang telah ditetapkan sebelumnya, pertanyaan disusun secara ketat dan pertanyaan sama pada setiap subjek (Sugiyono, 2015).

3. Dokumentasi

Dokumentasi adalah salah satu teknik pengumpulan data melalui dokumen atau catatan-catatan tertulis yang ada. Dokumentasi berasal dari kata dokumen, yang berarti barang-barang tertulis, didalam melaksanakan metode dokumentasi, peneliti menyelidiki benda-benda tertulis, seperti buku-buku, majalah, notula rapat, dan catatan harian.
Menurut Moleong dalam (Nasser, 2021) bahwa metode dokumentasi adalah cara pengumpulan informasi atau data-data melalui pengujian arsip dan dokumendokumen. Strategi dokumentasi juga merupakan teknik pengumpulan data yang diajukan kepada subyek penelitian. Metode pengumpulan data dengan menggunakan metode dokumentasi ini dilakukan untuk mendapatkan data tentang keadaan lembaga (obyek penelitian) yaitu keberadaan lembaga filantropi, keadaan lembaga filantropi, dan keadaan stafnya. Menurut Muhadjir dalam (Hanafiah, 2021) menyatakan bahwa analisis data merupakan kegiatan melakukan, mencari dan menyusun catatan temuan secara sistematis melalui pengamatan dan wawancara sehingga peneliti fokus terhadap penelitian yang dikajinya. Setelah itu, menjadikan sebuah bahan temuan untuk orang lain, mengedit, mengklasifikasi, dan menyajikannya.

Adapun pendekatan yang digunakan dalam penelitian ini adalah pendekatan kualitatif. Menurut Bogdan dan Taylor dalam (Bahri, 2021) menyatakan pendekatan kualitatif adalah prosedur penelitian yang menghasilkan data deskriptif berupa kata-kata tertulis atau lisan dari orang-orang dan perilaku yang dapat diamati. Caranya dengan mentranskripsikan data, kemudian pengkodean pada catatancatatan yang ada di lapangan dan diinterpretasikan data tersebut untuk memperoleh kesimpulan.

\section{HASIL DAN PEMBAHASAN}

A. Pembiayaan Pendidikan di Indonesia

Pendidikan merupakan salah satu pondasi penting yang dibangun dalam kehidupan dengan sebaik mungkin, secara global pendidikan bisa diartikan sebagai upaya pengembangan kualitas diri manusia dalam segala aspeknya. Pendidikan juga merupakan aktivitas yang sengaja dilakukan untuk mencapai tujuan tertentu dengan melibatkan berbagai macam faktor yang saling berkaitan satu dengan lainnya, sehingga membentuk sistem yang bisa saling mempengaruhi (Mahmud, 2011), menurut Undang-Undang Nomor. 20 tahun 2003 tentang Sistem Pendidikan Nasional bahwasannya Pendidikan merupakan usaha sadar dan terencana untuk mewujudkan suasana belajar dan proses pembelajaran agar peserta didik secara aktif mampu mengembangkan 
potensinya untuk memiliki kekuatan spiritual keagamaan, pengendalian diri, kepribadian, keceerdasan, akhlak mulia, serta ketrampilan yang diperlukan dirinya, masyarakat, bangsa dan negara. Pendidikan dipandang sebagai salah satu investasi sumber daya manusia, hal ini tidak terlepas dari tingginya biaya investasi pendidikan yang berkualitas. Dalam konteks penyelenggaraan pendidikan di tingkat negara (makro) maupun lembaga (mikro) pembiayaan dianggap sebagai sesuatu yang penting dan merupakan unsur yang harus tersedia dalam penyelenggaraan pendidikan (Irwansyah, 2021).

Pembiayaan pendidikan secara umum merupakan hal yang kompleksitas yang melibatkan satu komponen dengan komponen lainnya mulai ditingkat makro hingga mikro, yang meliputi sumber-sumber pembiyaan pendidikan, sistem dan mekanisme penganggarannya, efektivitas dan efisiensi penggunaannya, akuntabilitas hasil yang diukur dalam perubahan-perubahan yang terjadi pada semua aspek kususnya lembaga pendidikan, dan permasalahan-permasalahan yang masih mempunyai kaitan dengan pembiayaan pendidikan.

Menurut (Natsir, 2009) bahwa biaya pendidikan merupakan jumlah uang yang dihasilkan dan dibelanjkana untuk berbagai keperluan penyelenggaraan pendidikan yang meliputi gaji tenaga kependidikan, peningkatan kualitas sarana dan prasarana, pengadaan alat-alat dan buku pelajaran, kegiataan ekstrakurikuler, kegiataan pengelola pendidikan dan supervisi pendidikan, menurut (Supriyadi, 2003) bahwa Pembiayaan pendidikan merupakan salah satu komponen instrumen yang sangat vital dalam menyelenggarakan pendidikan. Biaya dalam definisi ini memiliki makna yang luas yakni seluruh biaya yang dikeluarkan yang berkaitan dengan penyelenggaraan pendidi-kan baik berbentuk uang maupun tenaga dan barang.

Dapat ditarik kesimpulan bahwa pembiayaan pendidikan merupakan hal yang urgent dalam penyelenggaraan pendidikan yang meliputi segala sesuatu yang yang bisa menunjang secara efektif penyelenggaraan pendidikan baik berupa uang, tenaga, maupun barang, pemerintah Republik Indonesia sesuai amanat Undang-Undang setiap tahun telah mencanangkan alokasi anggaran pendidikan sebesar minimun 20\% dari total Anggaran Pendapatan dan Belanja Negara (APBN) yang digulirkan melalui pemerintah daerah. Setiap tahun mencanangkan dan menetapkan anggaran untuk pendidikan yang dialokasikan untuk peningkatan kualitas SDM tenaga kependidikan, Bantuan Operasional Sekolah, dana insentif daerah, dan dana Percepatan Pembangunan Infrastruktur Daerah (PPID) Pendidikan (Supriyadi, 2003).

Landasan pembiayaan pendidikan secara makro mengacu kepada Undang-Undang yang tertuang sebagai berikut : 1) UU No. 20 Tahun 2003 Sistem Pendidikan Nasional Pasal 11 ayat 2 : Pemerintah dan pemerintah daerah wajib menjamin tersedianya dana guna menyelenggarakan pendidikan bagi setiap warganegaranya yang berusia tujuh sampai lima belas tahun, 2) UU No. 14 Tahun 2005 Tentang Guru dan Dosen Pasal 13 : Pemerintah dan Pemerintah Daerah wajib menyediakan anggaran untuk peningkatan kualifikasi akademik dan sertifikasi pendidik bagi guru dalam jabatan yang diangkat oleh satuan pendidikan yang disekenggarakan pemerintah, pemerintah daerah dan masyarakat, dan 3) Permendikbud RI Nomor 19 Tahun 2016 pasal 4 ayat 1 Tentang Program Indonesia Pintar. Program Indonesia Pintar diperuntukan bagi anak berusia 6 (enam) sampai dengan 21 (dua puluh satu) tahun dengan prioritas antara lain : a) Peserta didik pemegang KIP, b) Peserta didik dari keluarga miskin/rentan miskin dan/atau pertimbangan khusus, dan c) Peserta didik SMK yang menempuh studi keahlian kelompok bidang: Pertanian, Perikanan, Peternakan, Kehutanan dan Pelayaran/ Kemaritiman.

Konteks pembiayaan pendidikan secara mikro setiap lembaga pendidikan setiap tahun menyusun Anggaran Pendapatan dan Belanja Lembaga (RAPBL) yang digunakan sebagai acuan untuk membuat perencanaan pendapatan dan pengalokasian pembiyaan untuk keperluan operasional sekolah. Penyerapan biaya tersebut menggambarkan pola pembiayaan dalam pendidikan. Dengan hal tersebut bisa ditarik kesimpulan pembiyaan pendidikan adalah hal penting yang menentukan terselenggaranya pendidikan, pendidikan tidak akan terselenggara tanpa adanya pembiayaan. Pembiayaan pendidikan berasal dari berbagai sumber diantaranya biaya yang diberikan oleh pemerintah baik pemerintah pusat maupun daerah, orang tua/ wali siswa dan masyarakat luas (Nadeak, 2020). Sejalan dengan adanya Manajemen Berbasis Sekolah 
(MBS), lembaga pendidikan dapat menggali dan mencari sumber-sumber dana dari pihak masyarakat, baik secara perorangan maupun lembaga, dari dalam maupun luar negeri. Dana yang diperoleh dari berbagai sumber tersebut digunakan untuk kepentingan lembaga, khususnya kegiatan belajar dan mengajar yang efektif dan efisien. Setiap perolehan dana pengeluarannya harus didasarkan pada kebutuhan operasional yang telah disesuaikan dengan rencana anggaran pembiyaaan lembaga (Juhji, 2020).

Tingginya biaya pendidikan menjadikan sebagian masyarakat belum menikmati pendidikan secara optimal. Munculnya kebijakan pendidikan yang relatif mahal di berbagai lembaga menyebabkan sebagian masyarakat tidak mampu menjangkau pendidikan yang berkualitas, meskipun pemerintah telah mengalokasikan 20\% dari APBN untuk bidang pendidikan. Dewasa ini muncul banyak sekali gerakan sosial masyarakat yang bergerak dalam penghim-punan dana dan disalurkan untuk pendidikan bagi masyarakat yang kurang mampu. Gerakan ini dikenal dengan Filantropi yang merupakan sebuah usaha untuk saling tolong menolong dalam hal kemanusian termasuk dalam bidang pendidikan.

\section{B. Filantropi Sebagai Upaya Pembiayaan Pendidikan}

Sebagai sebuah gagasan gerakan di masyarakat, Filantropi memiliki arti "kedermawanan", "cinta kasih" terhadap sesama belum terlalu dikenal khalayak luas, meski secara praktis kegaiata filantropi telah menjadi bagian yang tidak terpisahkan dari kehidupan masyarakat di Indonesia. (Hilman, 2013) Konsep filantropi berkaitan langsung dengan rasa peduli, solidaritas dan hubungan sosial antar sesama manusia. Dalam perkembangan selanjutnya filantropi dimaknai dengan lebih luas yaitu kegiatan yang tidak hanya berkaitan dengan kegiatan berderma itu sendiri melainkan seberapa efektif kegiatan "memberi" baik materi maupun non-materi bisa mendorong perubahan dalam masyarakat.

Bila ditinjau dari aspek bahasa Filantropi (Philanthropy) berasal dari Bahasa Yunani, yang berasal dari kata Philos (berarti Cinta) dan Anthropos (berarti Manusia), sehingga secara harfiah Filantropi adalah implementasi dari memberi (giving), pelayanan (services), dan asosiasi (association). Yang secara sukarela membantu berbagai pihak yang membutuhkan sebegai ekspresi rasa cinta dan belas kasih.

Pada prakteknya Filantropi baik di Indonesia maupun di luar negeri tidak bisa dipisahkan dari peran agama yang melatar belakanginya. Ajaran agama menjadi implikasi pada bentuk-bentuk kegiatan Filantropi yang berkembang di masyarakat. Ditinjau dari sifatnya Filantropi dibagi menjadi dua yaitu Tradisional dan Modern (Chusnan, 2007). Filantropi tradisional adalah Filantropi yang merupakan bentuk dari rasa belas kasihan yang berbentuk pemberian untuk pelayanan sosial seperti halnya orang kaya membantu orang miskin. Bila dilihat dari orientasinya maka Filantropi tradisonal bersifat individual. Pada Filantropi Tradisonal terdapat sisi kekurangan diantaranya upaya filantropi ini dianggap menjadi hal yang memperpanjang relasi kekuasaan orang kaya terhadap orang miskin. Filantropi Modern diistilahkan juga Filantropi Keadilan Sosial. Filantropi yang ditangani oleh para kaum "Terpelajar" dengan menerapkan manajemen yang bermutu dalam kegiatannya, Filantropi ini diharapkan menjadi jembatan untuk mengatasi kesenjangan penyebab ketidakadilan dan kemiskinan.

Perkembangan dan penyebaran lembaga pendidikan Islam di Indonesia tidak terlepas dari kegiatan Filantropi mulai dari sekolah, madrasah, pesantren, hingga perguruan tinggi. Salah satu bentuk dari kegiatan Filantropi dalam bidang pendidikan adalah kegiatan wakaf, yaitu kegiatan menyerahkan aset dari pewakaf kepada orang yang diberikan wakaf yang dikelola menjadi lembaga pendidikan. Wakaf ini bisa berbetuk lahan ataupun bangunan tapi dalam era modern wakaf semakin luas lingkupnya.

Stenbrink dalam (Hasbi, 2021) bahwa sejarah perkembangan wakaf di Indonesia sangat besar dalam menunjang pelaksanaan pendidikan, melalui wakaf umat Islam mendapat kemudahan dalam menuntut ilmu. Wakaf dalam dunia pendidikan diperlukan untuk membiayai keperluan pengajaran dan memberikan tunjangan kesejahteraan kepada para pengajar. Sumber dana wakaf tidak hanya digunakan untuk membangun perpustakaan, ruang-ruang belajar, tetapi juga membangun perpustakaan, ruang belajar, tetapi jugas asrama dan kegiatankegiatan riset 
baik menggunakan metode empiris maupun scientific. Sebagai upaya untuk memotivasi riset, program penerjemahan juga ditunjang dari pendanaan hasil wakaf.

Lembaga wakaf menjadi sumber keuangan bagi lembaga Pendidikan islam. Adanya sistem wakaf dalam Islam dipengaruhi oleh sistem ekonomi Islam yang menganggap bahwa ekonomi berhubungan erat dengan akidah dan syariah Islam sehingga aktifitas ekonomi mempunyai tujuan ibadah dan kemaslahatan bersama (Mutmainnah, 2016), era modern saat ini, kegiatan Filantropi dikelola dengan manajemen pengelolaan yang baik dan semakin modern. Tumbuh banyak sekali lembaga Filantropi yang besar di Indonesia yang juga konsen dalam menangani pendidikan Islam di Indonesia, diantara lembaga Filantropi tersebut adalah Dompet Dhuafa yang didirikan pada tahun 1993 oleh beberapa wartawan yang terkumpul dalam media Republika, Rumah Zakat Indonesia yang didirikan Abu Syauqi di Bandung yang pad awal pendiriannya bernama Dompet Sosial Ummul Quro' (DSUQ) didirikan pada tahun 1998, Yayasan Dana Sosial al-Falah (YDSF) yang berbasis di Surabaya dan didirikan oleh Ahmad Kadir Baraja di tahun 1987, serta banyak lembaga Filantropi yang didirikan oleh para Da'i kondang diantaranya : Ustadz Yusuf mansyur mendirikan PPPA Darul Qur'an di tahun 2007, Ustadz Arifin Ilham mendirikan Adz-Dzikra pada tahun 1995, KH. Abdullah Gymnastiar mendirikan Darut Tauhid pada tahun 1990 dan banyak lagi lembaga Filantropi yang ada di Indonesia.

Lembaga Filantropi dewasa ini muncul dengan beraneka ragam dan memiliki kekhasan masing-masing, diantara lembaga Filantropi yang berkembang pesat saat ini adalah LAZNAS Yatim Mandiri yang memiliki konsen terhadap Kesejahteraan dan Pendidikan Yatim di Indonesia melalui programprogram yang digulirkannya.

C. Yatim Mandiri Sebagai Lembaga Filantropis Berbasis Pendidikan dan Kesejahteraan Yatim

Salah satu masalah pendidikan berkualitas di Indonesia adalah masalah pembiayaan pendidikan yang dianggap mahal bagi sebagian masyarakat dan mereka tak mampu menjangkaunya. Diantara mereka yang tak mampu menjangkaunya adalah mereka yang daya finansialnya kurang memadai akibat sumber pendapatan yang tak pasti. Salah satu kelompok masyarakat yang susah menjangkau pendidikan tinggi dan berkualitas adalah anak-anak yatim yang berasal dari keluarga miskin.

Yatim berasal dari bahasa Arab yang berasal dari kata "Yatama" atau "Aitam" adalah anak yang ditinggal oleh ayahnya sebab kematian dan belum mencapai usia dewasa (baligh) baik laki-laki atau perempuan, kaya atau miskin. Adapun anak yang bapak dan ibunya meninggal diistilahkan yatim piatu, bila yang meninggal adalah ibunya maka diistilahkan dengan piatu, Istilah piatu hanya dikenal di Indonesia dalam literature Fiqih dikenal hanya istilah yatim saja, bisa ditarik kesimpulan bahwa anak yatim adalah anak yang ditinggal mati oleh orang tuanya baik ayah maupun ibu sebelum mencapai usia dewasa dan membutuhkan rasa sayang serta bimbingan dari orang dewasa agar mampu menumbuhkan rasa percaya diri serta dapat menggali potensi yang dimiliki.

Salah satu Filantropi yang konsen terhadap pendidikan dan kesejahteraan bagi anak yatim adalah Yatim Mandiri. Yatim Mandiri adalah Lembaga Filantropi Nasional yang berkhidmat mengangkat harkat sosial kemanusian yatim dhuafa melalui dana yang dihimpun melalui Zakat, Infaq, shodaqoh, dan Wakaf yang berasal dari perorangan, kelompok maupun perusahaan. Kelahirannya berawal dari kumpulan aktivis Panti asuhan di Surabaya yang terdiri dari Sahid Has, Hasan sadzili, Sumarno, Syarif Mukhodam, dan Mohamad Hasyim. Kegelisahan yang dirasakan para aktivis melihat anak-anak yatim yang lulus Sekolah Menengah Atas (SMA) tidak bisa melanjutkan pendidikan karena keterbatas dana yang dimiliki panti asuhan di Surabaya.

Para aktivis yatim merancang sebuah yayasan yang bergerak dalam bidang pendidikan anak yatim purna asuh dari panti asuhan dengan program mengikutsertakan anak-anak yatim kursus sehingga mereka memiliki keterampilan untuk hidup (life skill), Yayasan yang dibentuk pada tanggal 31 maret 1994 dengan nama Yayasan Pembinaan dan Pengembangan Panti Asuhan Islam dan Anak Purna Asuh (YP3IS). Dalam perjalanannya YP3Is semakin berkembang dengan baik dan semakin profesional untuk memandirikan anak yatim melalui berbagai macam program yang digulirkannya. Terjadi banyak proses 
perubahan dalam perjalanan YP3IS baik secara manajemen kepengurusan yayasan maupun program yamg digulirkan untuk memperluas kemanfaatan untuk memandirikan anak yatim maka pada tanggal 22 Juli 2008 YP3IS berganti nama menjadi Yatim mandiri dengan nomor registrasi AHU2413.AH.01.02.2008 di Departemen Hukum dan Hak Asasai manusia (Depkumham). 21 Visi dari Yatim Mandiri "Menjadi lembaga terpercaya dalam membangun kemandirian yatim dan dhuafa". Misi dari Yatim Mandiri : 1) Membangun nilai-nilai kemandirian yatim dan dhuafa, 2) Meningkatkan partisipasi masyarakat dan dukungan sumberdaya untuk kemandirian yatim dan dhuafa, 3) Meningkatkan Capcity Building organisasi.

Yatim Mandiri memiliki berbagai macam program yang digulirkan baik dalam bidang Pendidikan, Pemberdayaan, Kesehatan, Kemanusiaan, Dakwah, Super Gizi Qurban dan Wakaf. Saat ini Yatim mandiri memiliki 60 cabang penghimpun dana Zakat, Infaq dan Sedekah (ZISWAF) yang tersebar di 60 kota dan 10 propinsi di Indonesia, penyusunan dalam menentukan anggaran pemasukan dan pengeluaran donasi setiap tahunnya dilakukakn dengan prinsip-prinsip transparansi dan akuntabilitas tinggi. Yatim Mandiri memiliki target "memandirikan anak yatim". Konsep pengembangan pembiayaan pendidikan yaitu dengan mendayagunakan zakat, infaq, sedekah dan wakaf sebagai pendapatan dana anggaran yang akan dialokasikan untuk pembangunan pendidikan.

Dalam bidang pendidikan dan pemberdayaan Yatim Mandiri memiliki program unggulan diantaranya:

1. Sanggar Al-Qur'an

Tujuan dari program ini adalah anak-anak binaan Yatim mandiri yang tersebar di setiap cabang Yatim Mandiri memiliki karkter yang baik, memhamai Al-Qur'an dengan baik dan benar serta menguasai dasar-dasar syariat Islam yang menjadi pedoman hidupnya

2. Kampus Kemandirian

Perkembangan ilmu saat ini semakin dinamis dan yatim mandiri terus bertransformasi menghadirkan dan memfasilitasi pendidikan anak yatim dan dhuafa dengan membuka perguruan tinggi yaitu : Sekolah Tinggi Agama Islam An-Najah Indonesia Mandiri (STAINIM) di Sidoarjo, Universitas Insan Cendekia Mandiri (UICM) di Bandung, Institut Tekonologi Insan Cendekia Mandiri (ITICM) di Sidoarjo.

3. Insan Cendikia Mandiri Boarding School (ICMBS)

ICMBS menjadi kawah candradimuka bagi peserta didik dalam upaya membangun nilai-nilai kemadririan dan menggapai citacita. Peserta didik merupakan siswa SMP dan SMA yang terpilih dari seluruh Indonesia yang mendapatkan beasiswa pendidikan Formal dan Boading School.

4. Rumah Kemandirian

Menggabungkan dua program sekaligus yakni sanggar Genius dan Sanggar Alqur'an dalam satu kesatuan menjadi program "Rumah Kemandirian". Yatim Mandiri memberikan wadah bagi anakanak yatim dan dhuafa yang masih duduk di jenjang SD/MI atau sederajat untuk mengembangkan kemampuan baik akademik maupun bakat yang dimilikinya

5. Sanggar Genius

Lahirnya program "Guru Excellent Yatim Sukses" (GENIUS) berawal dari kepedulian Yatim mandiri terhadap pendampingan dan bimbingan akdemik anak khusunya mata pelajaran Matematika menghadirkan program yang telh dirasakan oleh anak di 500 titik Sanggar Genius yatim mandiri yang tersebar di seluruh Indonesia.

6. Mandiri Enterpreuner Center (MEC)

Program MEC menjadi program penggabungan Pendidikan dan Kemandirian, program ini bertujuan memberikan bekal ketrampilan, pengembangan mental amndiri dan akses dunia kerja atau wirausaha.

Penelitian tentang pembiayaan pendidikan ini memfokuskan kepada program Mandiri Enterpreuner Center (MEC) yang merupakan sebuah upaya untuk mendidik, mengkader dan memberdayakan anak yatim sehingga mampu mendapatkan pendidikan dengan layak, memiliki Life Skill dan memiliki jiwa usaha sehingga kelak mereka mandiri serta memiliki sumbangsih terhadap lingkungan sekitar.

D. Mandiri Enterpreuner Center (MEC) Sebuah Upaya Pendidikan dan Pengkaderan Mahasiswa Yatim

Kunci sebuah kemajuan bangsa terletak pada generasi penerus yakni para pemudanya, untuk itu diperlukan upaya dan kerja keras untuk mendidik dan mengembangkan segala 
potensi yang ada dalam diri mereka. Yatim Mandiri memiliki kepedulian kepada generasi muda terbukti dengan digulirkannya program Mandiri Enterpreuner Center (MEC). MEC merupakan salah satu program unggulan yang digulirkan Yatim Mandiri, MEC sendiri merupakan program pendidikan dan pelatihan yang diperuntukan bagi purna Yatim yang berada dalam rentang usia 17 - 21 tahun. Tujuan dari progam ini ialah mencetak enterpreuner yatim dengan pembekalan tiga pilar yaitu akademik, keagamaan dan wirausaha.

Dana pembiyaan pendidikan program MEC diperoleh dari Yatim Mandiri yang mengalokasikan sebesar 7\% dari keseluruhan dana yang dihimpun Yatim Mandiri. Menurut Ustadz Muklis selaku pengurus dan manajenem MEC setiap mahasiswa MEC akan memperoleh dana sebesar Rp.32 juta selama masa pendidikan satu tahun di asrama MEC. Dana ini dipergunakan sebagai pembiayaan pendidikan dan asrama selama satu 20 tahun, terhitung sejak mahasiswa mendaftar dan menyelesaikan tahapan pendidikan dan pengkaderan selama satu tahun. Sampai tahun 2020 MEC telah meluluskan 1800an mahasiswa yang tersebar di seluruh Indonesia, MEC memiliki lima cabang saat ini yaitu : 1) MEC Pusat Surabaya, 2) MEC Putri Semarang, 3) Pesantren Kemandirian Putra Sragen, 4) MEC Palembang Putri, dan 5) MEC Jakarta.

MEC memiliki lima jurusan yang bisa dipilih mahasiswanya sesuai keinginan mereka, enam jurusan tersebut terdiri dari : 1) Akuntansi dan Administrasi Perkantoran, 2) Teknisi Komputer dan Jaringan, 3) Desain Grafis dan Multimedia, 4) Otomotif, dan 5) Agro Industri (Pertanian dan Peternakan), dalam bidang keagamaan para mahasiswa MEC ditempatkan dalam asarama dan menjalankan program pembiasaan ibadah, kegamaan dan materi Madrasah Diniyah yang wajib diikuti. Dalam bidang kegamaan MEC bekerjasama dengan berbagai pihak diantaranya Pesantren Moderen Gontor, Tilawati sebagai pusat pembelajara Al-Qur'an, dalam bidang Enterpreuner MEC menerapakan enam langkah yaitu :

1. Enterpreuneur Camp

Suatu program yang membangun karakter para mahasiswa, menitik beratkan kepada kesiapan mental dan kemandirian mahasiswa. Program ini berlangsung selama satu minggu di awal tahun perkuliahan. Mahasiswa akan dibagi dalam beberapa kelompok dan disebar radius lima Kilometer dari asrama dan diminta untuk menjalankan kegiatan wirausaha dan poyensi usaha di wilayah tersebut serta bisa membawa uang hasil program tersebut. Program ini mengajarkan mahasiswa untuk mengintegrasikan antara komunikasi, negosisasi, membangun jaringan, membangun karakter dan praktek jual beli di lapangan.

2. Enterpreuner Session

Suatu program yang merupakan lanjutan dari program Enterpreuner Camp, yang membedakan adalah para mentor turut mengevaluasi program ini dan memberikan masukan kepada para mahasiswa terkait tugas enterpreuneur yang mereka jalankan. Program ini dilaksanakan di hari Sabtu dan Ahad. Dalam program ini mahasiswa diberikan pengetahuan dan keterampilan untuk memaarkan produk kepada para konsumen.

3. Enterpreuner Motivation

Program ini dilaksanakan setiap hari Jumat dengan menghadirkan para motivator nasional yang handal di bidangnya dan para alumni MEC yang sudah sukses untuk memberikan motivasi kepada para mahasiswa. Program ini bertujuan memotivasi para mahasiwswa agar bisa sukses dalam wirausaha.

4. Enterpreuner Challenge

Dalam program ini mahasiswa dituntut untuk melaksanakan kegiatan wirausaha dengan lokasi di pusat kota. Para mahasiswa dilepas dan tidak dibekali dengan uang namun mereka harus membawa hasil wirausaha sesuai target yang ditentukan. Program ini bertujuan agar mahasiswa lebuh inovati, kreatif dan mampu menaklukan tantangan yang ada di hadapannya.

Empat program wirausaha tersebut memiliki tujuan untuk memotivasi, mengembangkan, memberikan bekal kewirausahaan kepada para mahasiswa. Hal ini juga memperkuat teori yang sudah mereka dapatkan di kegiatan akademik perkuliahan mahasiswa. Hasil dari program wirausaha wajib ditabung kepada pembina dan kelak akan diberikan sebagai tambahan modal usaha bila sudah menyelesaikan program pendidikan di MEC. Dari proses kegiatan 
kewirausahaan di MEC yang diimbangi teori dan praktek juga didukung lingkungan yang memiliki atmosfer enterpreunership diharapkan mahasiswa kelak menjadi seorang wirausaha dan menjadi pribadi yang mandiri, baik mandiri secara ibadah, keilmuaan serta financial. Sesuai dengan Visi Yayasan Yatim Mandiri yakni "menjadi lembaga terpercaya dalam membangun kemandirian yatim".

\section{SIMPULAN DAN SARAN}

\section{A. Simpulan}

Pembiayaan pendidikan merupakan hal yang urgent dalam penyelenggaraan pendidikan yang meliputi segala sesuatu yang yang bisa menunjang secara efektif penyelenggaraan pendidikan baik berupa uang, tenaga, maupun barang. Pembiyaan pendidikan adalah hal penting yang menentukan terselenggaranya pendidikan. Pendidikan tidak akan terselenggara tanpa adanya pembiayaan. Tingginya biaya pendidikan menjadikan sebagian masyarakat belum menikmati pendidikan secara optimal. Munculnya kebijakan pendidikan yang relatif mahal di berbagai lembaga menyebabkan sebagian masyarakat tidak mampu menjangkau pendidikan yang berkualitas, meskipun pemerintah telah mengalokasikan $20 \%$ dari APBN untuk bidang pendidikan. Dewasa ini muncul banyak sekali gerakan sosial masyarakat yang bergerak dalam penghimpunan dana dan disalurkan untuk pendidikan bagi masyarakat yang kurang mampu. Gerakan ini dikenal dengan Filantropi yang merupakan sebuah usaha untuk saling tolong menolong dalam hal kemanusian termasuk dalam bidang pendidikan. Salah satu Filantropi yang konsen terhadap pendidikan dan kesejahteraan bagi anak yatim adalah Yatim Mandiri. Yatim Mandiri adalah Lembaga Filantropi Nasional yang berkhidmat mengangkat harkat sosial kemanusian yatim dhuafa melalui dana yang dihimpun melalui Zakat, Infaq, shodaqoh, dan Wakaf yang berasal dari perorangan, kelompok maupun perusahaan. Kelahirannya berawal dari kumpulan aktivis Panti asuhan di Surabaya yang terdiri dari Sahid Has, Hasan sadzili, Sumarno, Syarif Mukhodam, dan Mohamad Hasyim. Yatim Mandiri memiliki kepedulian kepada generasi muda terbukti dengan digulirkannya program Mandiri Enterpreuner Center (MEC). MEC merupakan salah satu program unggulan yang digulirkan
Yatim Mandiri, MEC sendiri merupakan program pendidikan dan pelatihan yang diperuntukan bagi purna Yatim yang berada dalam rentang usia 17 - 21 tahun. Tujuan dari progam ini ialah mencetak enterpreuner yatim dengan pembekalan tiga pilar yaitu akademik, keagamaan dan wirausaha. Dana pembiyaan pendidikan program MEC diperoleh dari Yatim Mandiri yang mengalokasikan sebesar 7\% dari keseluruhan dana yang dihimpun Yatim Mandiri. Menurut Ustadz Muklis selaku pengurus dan manajenem MEC setiap mahasiswa MEC akan memperoleh dana sebesar Rp.32 juta selama masa pendidikan satu tahun di asrama MEC. Dana ini dipergunakan sebagai pembiayaan pendidikan dan asrama selama satu tahun, terhitung sejak mahasiswa mendaftar dan menyelesaikan tahapan pendidikan dan pengkaderan selama satu tahun.

\section{B. Saran}

Berdasarkan hasil kesimpulan penelitian, dapat dikemukakan beberapa saran untuk ditindak lanjuti, baik bagi penelitian yang akan datang maupun pihak MEC Yatim Mandiri. Adapun saran tersebut sebagai berikut:

1. Dengan makin berkembangnya Yatim Mandiri diperlukan strategi diversifikasi pengumpulan dana, untuk itu Yatim Mandiri dapat melakukan usaha agar tidak mengandalkan sumbangan dari filantropi.

2. Untuk penelitian sejenis dapat dilakukan kajian lebih mendalam secara kuantitatif mengenai aspek keuangan.

3. Untuk penelitian selanjutnya dapat melakukan kajian pengembangan strategi pengumpulan dana, pengembangan program kewirausahaan dan lain-lain.

\section{DAFTAR RUJUKAN}

Arifudin, O. (2021). Manajemen Pembiayaan Pendidikan. Bandung: Widina Bhakti Persada.

Arikunto, S. (2006). Prosedur Penelitian Suatu Pendekatan Praktik. Jakarta : Rieneka Cipta.

Bahri, A. S. (2021). Pengantar Penelitian Pendidikan (Sebuah Tinjauan Teori dan Praktis). Bandung: Widina Bhakti Persada.

Baznas. (2020). Pusat Kajian Strategis Baznas Outlook Zakat Indonesia. Jakarta : Baznas. 
Chusnan. (2007). Filantropi Modern untuk Pembangunan Sosial. Jurnal Penelitian Dan Pengembangan Kesejahteraan Sosial, 12(1), 74-80.

Fasa, I. (2020). Eksistensi Bisnis Islami Di Era Revolusi Industri 4.0. Bandung: Widina Bhakti Persada.

Ferdi. (2013). Pembiayaan Pendidikan: Suatu kajian Teoritis. Jakarta: Puslitjak, Balitbang, Kemendikbud.

Hanafiah. (2021). Pelatihan Software Mendeley Dalam Peningkatan Kualitas Artikel Ilmiah Bagi Mahasiswa. Jurnal Karya Abdi Masyarakat, 5(2), 213-220.

Hasbi, I. (2021). Administrasi Pendidikan (Tinjauan Teori Dan Praktik). Bandung: Widina Bhakti Persada.

Hilman. (2013). Filantropi dan Pendidikan Islam di Indonesia. Jurnal MP, 28(1), 123-139.

Irwansyah, R. (2021). Perkembangan Peserta Didik. Bandung: Widina Bhakti Persada.

Juhji. (2020). Manajemen Humas Sekolah. Bandung: Widina Bhakti Persada.

Labetubun, M. A. H. (2021). Sistem Ekonomi Indonesia. Bandung : Widina Bhakti Persada.

Mahmud. (2011). Pemikiran Pendidikan Islam. Bandung : Pustaka Setia.

Murtika. (2017). Strategi Pembiayaan Pendidikan Berbasis Filantropi Islam dalam Memberdayakan Anak Yatim di Yayasan Yatim Mandiri Surabaya. Malang: JMPI UIN Malang.
Mutmainnah. (2016). Wakaf dan Pengembangan Pendidikan Islam di Indonesia. Jurnal of Islamic Educations Studies, 1(1), 32-45.

Nadeak, B. (2020). Manajemen Humas Pada Lembaga Pendidikan. Bandung: Widina Bhakti Persada.

Nasser, A. A. (2021). Sistem Penerimaan Siswa Baru Berbasis Web Dalam Meningkatkan Mutu Siswa Di Era Pandemi. Biormatika: Jurnal Ilmiah Fakultas Keguruan Dan Ilmu Pendidikan, 7(1), 100-109.

Natsir. (2009). Ekonomi dan Pembiayaan Pendidikan. (Bandung: PT.Remaja Rosdakarya.

Rahayu, Y. N. (2020). Program Linier (Teori Dan Aplikasi). Bandung : Widina Bhakti Persada.

Shofa. (2017). Filantropi Islam untuk Pendidikan: Strategi Pendanaan Dompet Dhuafa dalam Program Sekolah Guru Indonesia (SGI), Universitas Islam Negeri (UIN) Sunan Kalijaga Yogyakarta. Madania, 21(1), 21-33.

Sugiyono. (2015). Metode Penelitian Pendidikan (Pendekatan Kuantitatif,. Kualitatif dan $R \& D)$. Bandung : CV. Alfabeta.

Supriyadi. (2003). Satuan Biaya Pendidikan Dasar dan Menengah. Bandung: PT. Remaja Rosdakarya.

Wibisono. (2007). Membedah Konsep dan Aplikasi CSR (Corporate Social Responsibility)". Gresik: Fascho Publishing. 